\section{RECONSTRUCTION OF DYSFUNCTIONAL URBAN CORRIDORS: CASE STUDY CAIRO}

\author{
Slobodan Nešković, Ph.D., Economy \\ University Business Academy, Faculty of economics and engineering \\ management, Novi Sad, slobneskovic@gmail.com
}

\begin{abstract}
Assoc. Prof. Igor Jokanović, Ph.D., CE
University of Novi Sad, Faculty of Civil Engineering, Subotica, jokanovici@gf.uns.ac.rs
\end{abstract}

Gradimir Stefanović, M.Sc. TE

GSTC Ltd., stefgrad@btinternet.com

DOI: 10.31075/PIS.64.04.02

Professional paper

Abstract: Urban corridors consist of high capacity streets serving fast passenger traffic and public transport, however frequently with severe deficiencies in operation and structural characteristics resulting in high impact to population and economy. The most significant impacts are reflected in the domain of pollution, traffic safety and large time losses. The paper outlines the methodological approach for the analysis of current conditions and measures proposed to improve level of service for public and individual transport within the corridor, as well as the measures for improving quality of life along the corridor.

Keywords: corridor, reconstruction, quality of life, public transport, measures

\section{REKONSTRUKCIJA DISFUNKCIONALNIH URBANIH KORIDORA: STUDIJA SLUČAJA KAIRO}

Prof. dr Slobodan Nešković, dipl.ecc.

Univerzitet privredna akademija, Fakultet za ekonomiju i inženjerski menadžment, Novi Sad, slobneskovic@gmail.com

Prof. dr Igor Jokanović, dipl.građ.inž.

Univerzitet u Novom Sadu, Građevinski fakultet, Subotica, jokanovici@gf.uns.ac.rs

mr Gradimir Stefanović, dipl.saob.inž.

GSTC Ltd., stefgrad@btinternet.com

Stručni rad

Sažetak: Urbani koridori se sastoje od ulica velikih kapaciteta koji služe za brzi putnički saobraćaj i javni prevoz, ali često $s$ ozbiljnim nedostacima $u$ eksploataciji i konstruktivnim karakteristikama koji rezultiraju značajnim uticajem na stanovništvo $i$ ekonomiju. Najznačajniji uticaji se odražavaju u području zagađenja, bezbednosti saobraćaja $i$ velikih gubitaka vremena. $U$ radu se prikazuje metodološki pristup analizi postojećih uslova i mere predložene za poboljšanje nivoa usluge javnog $i$ individualnog saobraćaja unutar koridora, te mere za poboljšanje kvaliteta života duž koridora.

Ključne reči: koridor, rekonstrukcija, kvalitet života, javni transport, mere

\section{INTRODUCTION}

In the complex system of the city as a whole, traffic has a dual role. On one hand, traffic as a fluid, combines urban amenities, directs and coordinates the activities and defines pace of the city life. On the other hand, traffic infrastructure encloses space for the development of physical structures, so that the traffic is an inevitable factor in the spatial organization of the city. Although street infrastructure is largely in place in most of the cities worldwide, it is very difficult to accomplish its full functionality. With incomplete functionality, such system carries two very significant social, economic and financial consequences - traffic safety and environmental pollution.

Considering that more than 1.2 million people die each year on the world's roads [1] it is clear why the United Nations General Assembly adopted the resolution in 2010 that led to the establishment of the Decade of Action for Road Safety (2011-2020). The resolution called on Member States to take the necessary steps for making their roads safer.

Most of these deaths are in low- and middle-income countries where rapid economic growth has been accompanied by increased motorization and road traffic injuries. As well as being a public health problem, road traffic injuries are a development issue: low- and middle-income countries lose approximately $3 \%$ of GDP (Gross Domestic Product) as a result of road traffic crashes [1]. Infrastructure development and management, as well as traffic management, have not been able to keep the pace with such growth.

From the environmental point, global emissions of carbon dioxide $\left(\mathrm{CO}_{2}\right)$ have increased by almost $50 \%$ since 1990 [2, 3], while transport accounted for almost a quarter of $\mathrm{CO}_{2}$ emissions from global energy use in 2013 [2]. Transportation sector is very energy intensive and it uses petroleum based fuels almost exclusively to meet those needs. Road transport accounts for three quarters of the sector's $\mathrm{CO}_{2}$ emissions [2]. Automobiles, freight and light-duty trucks are the main sources of emissions for the whole transport sector, and emissions from these three have steadily grown since 1990. Emissions caused by the transportation of people and goods have grown so rapidly that they have surpassed emissions from the industrial sector (Figure 1).

In September 2015, heads of states attending the United Nations General Assembly adopted the historic Sustainable Development Goals (SDGs) [3]. One of the new SDG targets (3.6) is to halve the global number of deaths and injuries from road traffic crashes by 2020 . 
Furthermore, SDG target 11.2 calls for provision of access to safe, affordable, accessible and sustainable transport systems for all, improving road safety, notably by expanding public transport, by 2030. Finally, on the environmental side, SDG target 3.9 asks for substantial reduction of the number of deaths and illnesses from hazardous chemicals and air, water and soil pollution and contamination by 2030, and (SDG target 9.4) to upgrade infrastructure and retrofit industries to make them sustainable, with increased resource-use efficiency and greater adoption of clean and environmentally sound technologies and industrial processes.

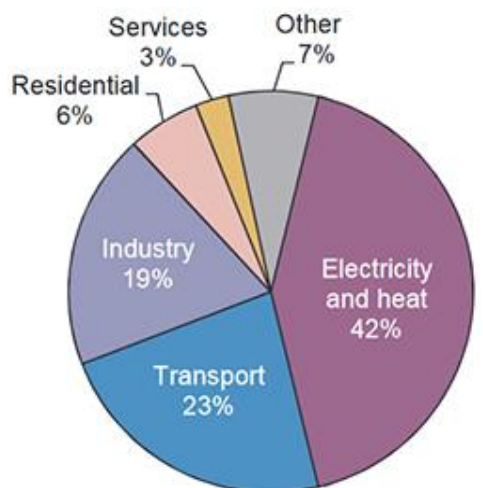

Figure 1. Carbon dioxide emissions from fossil fuel combustion in 2013 [2]

As a part of the overall transportation system, streets occupy approximately $20 \%$ of the total land area in a typical city, and they are the most important and ubiquitous form of public space. Streets are the stage upon which the drama of urban life unfolds every day. And this is not a recent phenomenon - streets have played this role since the beginning of towns and cities. At the moment, cities need to set new goals for their streets if they are to meet the needs of a dynamic and growing city and address the problems of vehicle crashes, traffic congestion, poor-performing bus and bike networks, and environments that are inhospitable for pedestrians. Making streets more efficient, not simply widening them, can help solve mobility problems. Mobility can be provided through high quality, high capacity public transport, which does not necessarily mean moving large numbers of vehicles.

\section{CORRIDOR DEVELOPMENT}

The largest number of urban settlements has significant inherited structures as a result of centuries of change. Usually, the final phase is a condition resulting from the continuous expansion of urban areas. Starting from this stage, three alternative concepts of urban development can be formulated, namely: continuous expansion, corridor development and development of secondary agglomerations.
Corridor development locates city facilities along major traffic corridors. This concept supports high capacity forms of public transport with the possibility of reducing the pressure of passenger cars on the main city center. The transport system has an important role for corridor development by providing accessibility through enabling access for localized content, and as an initiator to implement such concept. In other words, the transportation system and the quality of its supply of services can initiate, control and accelerate the formation of the optimal spatial model of the city in the future, i.e. to have causal role. The style of the corridor has the opportunity to bring all future transport effects (road, bus, underground services, cycling, walking) within the single widened transportation corridor. In this way it will reduce their incremental impacts on the urban area. Through corridor development, concentrated impacts (primarily air pollution and noise) are far less manifested on relatively small and limited space with normal daily activities of citizens [4]. At the same time, traffic management and traffic safety control are much easier.

Urban corridor areas are "very public" open spaces used and viewed intensively by the majority of population. They should be of sufficient width to enable quality design and include sympathetic quality traffic architecture. Corridors are permanent and dynamic features of urban form to be used, observed and admired by the population at large and their design should add to the public image of a city's "map of interest and delight".

Following the trends in provision of public transport services, road safety and climate impacts, and trying to solve its huge transport problems, Cairo Governorate has realized that the Nasr City Branch of the Heliopolis Tram presents huge risk for traffic safety, and in 2014 transformed this non-functional corridor into a segregated bus way with two lanes (one in each direction) with a length of $6.4 \mathrm{~km}$. While the new bus way has indeed improved traffic conditions, several problematic issues became apparent when the corridor operation commenced, primarily in the areas of bus operations, traffic management and road safety.

This clearly shows that planning and management of the Cairo transport system largely consists of a project based approach. As a consequence, the current planning lacks a comprehensive vision as well as clear objectives, and favors short-term local remedies allowing temporary improvements or limiting damage, but without considering their longterm consequences and their impacts on the whole transport system. In the absence of a planning function for urban transport, there cannot be any coordination between urban development and urban transport despite its importance. 
Mostafa El Nahas corridor, practically being dysfunctional, has negative impact on Cairo population. These negative impacts are mostly represented through increased noise levels and air pollution, having disruption to normal life and work conditions, and low traffic safety, which leads to increased death rate and accidents. Therefore, the Governor of Cairo has requested the international community to provide assistance in developing a comprehensive plan to enhance the functional effectiveness of the Mostafa EI Nahas corridor. The plan should enable improvement of the corridor and thereby:

(i) ensure that segregated bus lanes are showcased as a success and not brought into disrepute by poor design, implementation or maintenance, and

(ii) provide a model for future candidate corridors to be developed in Cairo by building on the existing success and replicating this city-wide.

Components of the asset management comprehensive approach to the road management and its optimization can be applied in phases, merged and split according to the conditions and to the system maturity. It can be scaled back to components that are needed at a certain time, but it allows for a well-organized and optimized approach.

\section{METHODOLOGICAL APPROACH}

Planning and/or design include more or less formalized procedures with the goal to look forward into the future with sufficient certainty and reliability, and make the necessary decisions followed by appropriate measures to improve the existing condition in order to realize positive and minimize the negative effects of development. A methodological approach to the mid-20th century consisted of a linear sequential structure of four steps, namely: analysis of the current conditions - forecast of future conditions establishing measures - implementing measures.

The essence of the newer approach is the comparison among the current and desired conditions which can identify shortcomings that must be corrected in the future. Such a process can generally be broken down into four steps shown in Figure 2.

The first step is the analysis of the problem where the desired condition is being defined through the objectives of development, and deficiencies are based on the results of the analysis of the current situation. In the second step all measures (political, organizational, management, construction, operational, etc.) are defined, followed by the analysis of the possible consequences of the implemented measures.
Decision-making involves the review and adoption of optimal measures, through professional and political structures, and the general public. The last step is a continuous process of implementation of adopted measures, with the obligation for constant checkup whether the consequences of applied measures are consistent with those defined in the design.

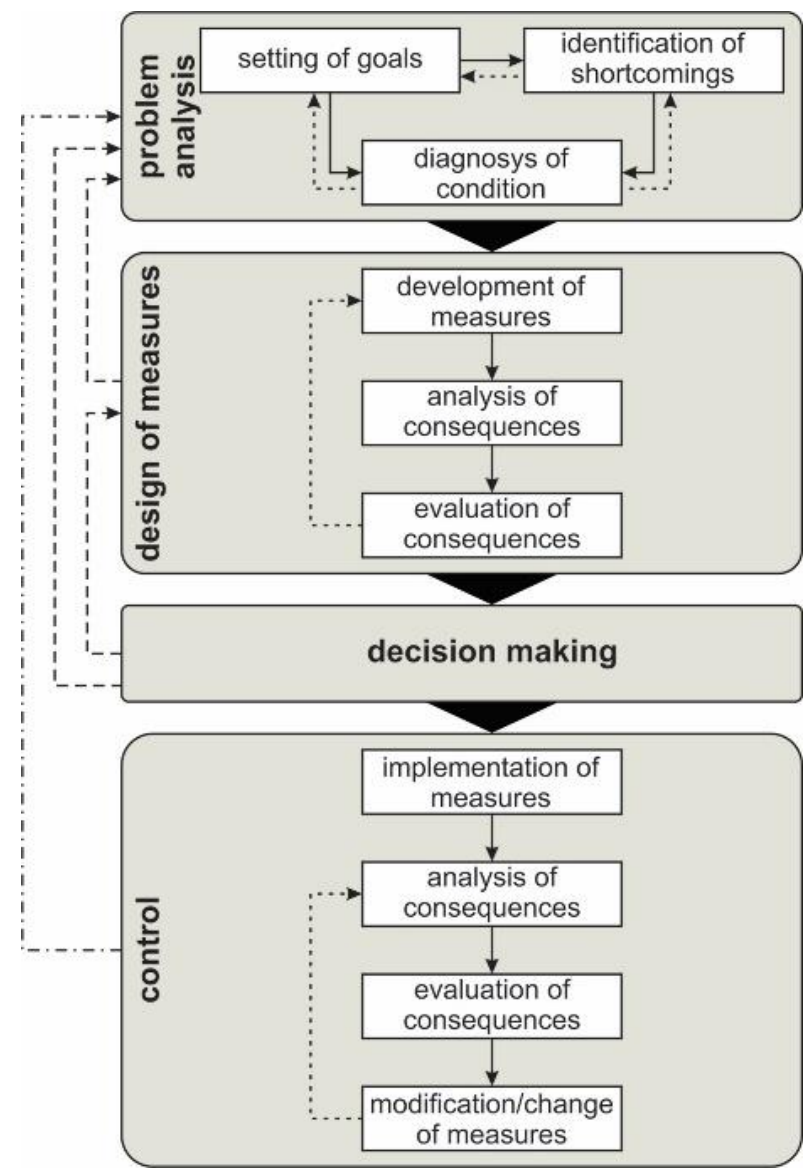

Figure 2. Basic methodological steps of planning and/or design process [5]

Methodological approach described above has been implemented during analysis of the Mostafa EI Nahas corridor and development of reconstruction measures.

\section{MOSTAFA EL NAHAS CORRIDOR CHARACTERISTICS}

The corridor area is combined of two sub-corridors, each divided in two directions A and B (Figure 3), namely:

- I: Mostafa El Nahas - Mahdy Arafa Str. and I-1: Yossef Abas Str.;

- II: Ahmed El Zamor - Abdul El Araby Str. - EI Tarayan Str.

These segments were originally designed for high capacity public and individual passenger traffic with the function of connecting the individual parts of the city with the center and activity zones. 
Number of bus routes operate along existing bus way infrastructure, while the extension I-1 covers several extended bus routes also operating along the main branch of the sub-corridor I.

Total length of 77 bus lines operating along the Mostafa El Nahas corridor area is about $3,685 \mathrm{~km}$ (both directions $A$ and $B$ ), having four types of bus stops (Table 1): official and unofficial stops along the street for buses travelling outside the bus lanes, and official and unofficial stops along the bus lanes.

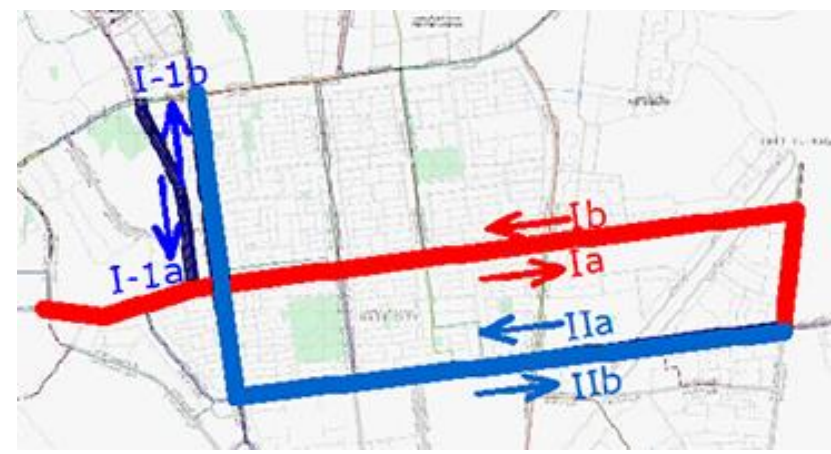

Figure 3. Two sub-corridors within the project area [6]

Travel time data (Table 2) were collected on segments along the corridor streets during morning and afternoon peak and off-peak periods, both for week days and Saturday, as well as travel time during evening peak (Wednesday). Peak period travel times are significantly higher than off-peak travel times, with the largest difference (about 2.4 times) recorded for direction $A$ along the Ahmed Al Zamor Str. Variation between directions confirms a well-known fact for urban infrastructure on equalization of traffic volumes in different directions of flow during the day (unevenness of flows to and from the city center depending on the time of day). Analysis of average speed, calculated on the basis of the travel time data, showed its variation along the corridor depending on the period of the day and direction, but also depending of day in week:

- minimum value is $4.7 \mathrm{~km} / \mathrm{h}$ in direction $A$, evening peak on Wednesday;

- maximum value is $23.7 \mathrm{~km} / \mathrm{h}$ in direction $\mathrm{B}$, morning off-peak period, during weekdays.

Table 1. Stops inside the corridor area [6]

\begin{tabular}{|c|c|c|}
\hline type of stop & direction A & direction B \\
\hline official stops outside bus lanes & 8 & 11 \\
\hline $\begin{array}{c}\text { unofficial stops outside bus } \\
\text { lanes }\end{array}$ & 8 & 8 \\
\hline official stops in bus lanes & 14 & 8 \\
\hline unofficial stops in bus lanes & 1 & 5 \\
\hline total stops & 31 & 32 \\
\hline
\end{tabular}

In parallel, ridership data were available for 14 out of 77 lines (all operated by buses with average number of buses per line being 5.86). Total ridership reaches 1.84 million per month, 131,456 per bus line/month. Average ridership per bus is 22,443 per month.
Table 2. Travel time survey data during weekdays [6]

\begin{tabular}{|c|c|c|c|c|c|c|}
\hline \multirow{2}{*}{$\begin{array}{l}\text { segment/str } \\
\text { eet }\end{array}$} & \multirow{2}{*}{$\begin{array}{c}\text { segmen } \\
\text { t length } \\
{[\mathrm{m}]}\end{array}$} & \multirow{2}{*}{ direction } & \multicolumn{2}{|c|}{$\begin{array}{l}\text { travel time } \\
\text { [sec] }\end{array}$} & \multicolumn{2}{|c|}{$\begin{array}{c}\text { average } \\
\text { speed } \\
{[\mathrm{km} / \mathrm{h}]}\end{array}$} \\
\hline & & & $\begin{array}{c}\text { PM } \\
\text { peak }\end{array}$ & $\begin{array}{l}\text { off- } \\
\text { peak }\end{array}$ & $\begin{array}{c}\text { PM } \\
\text { peak }\end{array}$ & $\begin{array}{l}\text { off- } \\
\text { peak }\end{array}$ \\
\hline \multirow{2}{*}{$\begin{array}{l}1 \text { Mostafa } \\
\text { El Nahas }\end{array}$} & \multirow{2}{*}{3,950} & A & 1,020 & 660 & 13.9 & 21.5 \\
\hline & & $B$ & 960 & 600 & 14.8 & 23.7 \\
\hline \multirow{2}{*}{$\begin{array}{l}2 \text { Mahdy } \\
\text { Arafa }\end{array}$} & \multirow{2}{*}{950} & A & 720 & 660 & 4.7 & 5.2 \\
\hline & & $B$ & 480 & 360 & 7.1 & 9.5 \\
\hline \multirow{2}{*}{$\begin{array}{l}3 \text { Ahmed Al } \\
\text { Zamor }\end{array}$} & \multirow{2}{*}{4,700} & A & 2,280 & 960 & 7.4 & 17.6 \\
\hline & & $B$ & 1,217 & 788 & 13.9 & 21.5 \\
\hline \multirow{2}{*}{$\begin{array}{l}4 \mathrm{Al} \\
\text { Tarayan }\end{array}$} & \multirow{2}{*}{2,170} & A & 1,263 & 633 & 6.2 & 12.3 \\
\hline & & $B$ & 852 & 662 & 9.2 & 11.8 \\
\hline
\end{tabular}

Additionally, ridership data were collected along the streets that form the corridor (number of passengers observed at each stop).

Taking into account that vehicles entering the corridor area are already occupied at certain degree, surveyors assessed number of passengers in those vehicles (Tables 3. and 4).

Again, as with the travel time, number of passengers is being equalized between directions during the day (uneven number of passengers to and from the city center depending on the time of day).

Since the development of the bus way on the Mostafa El Nahas corridor in 2014, certain improvements in the quality of public transport became noticeable. The speed of public buses along Mostafa El Nahas and Mahdy Arafa streets became higher than on the other streets in the area that do not have bus ways. Several legal parking locations, totalling approximately 1,700 car spaces, were established along Mustafa El Nahas Str.

Also, the Mostafa El Nahas corridor has six wellorganized (structurally and in terms of traffic flow organization) intersections with local streets: Youssef Abbas/Ali Amin, Al Tayaran/Ali Amin, Abbas El Akad/Mostafa El Nahas, Makram Ebeed/Mostafa El Nahas, Africa/Mahdy Arafa and Mahdy Arafa/Ahmed El Zomor.

Table 3. Passenger flow characteristics [pass/hour] at subcorridor I [6]

\begin{tabular}{|l|c|c|c|}
\hline \multicolumn{1}{|c|}{ street } & period & direction A & direction B \\
\hline Mostafa El & morning peak & $999-2,319$ & $1,353-4,224$ \\
Nahas Str. & afternoon peak & $1,575-2,932$ & $1,497-3,096$ \\
& off peak & $822-3,144$ & $824-1,745$ \\
\hline Mahdy & morning peak & $100-180$ & $100-180$ \\
Arafa Str. & afternoon peak & $446-850$ & $446-850$ \\
(estimate) & off peak & $82-174$ & $82-174$ \\
\hline
\end{tabular}


Table 4. Passenger flow characteristics [pass/hour] at subcorridor II [6]

\begin{tabular}{|l|c|c|c|}
\hline \multicolumn{1}{|c|}{ street } & period & direction A & direction B \\
\hline Ahmed El & morning peak & $3,209-3,860$ & $797-1,516$ \\
Zamor & $\begin{array}{c}\text { afternoon peak } \\
\text { off peak }\end{array}$ & $\begin{array}{c}829-2,485 \\
1,079-1,954\end{array}$ & $\begin{array}{c}792-1,128 \\
1,292-1,464\end{array}$ \\
\hline \multirow{2}{*}{ Abdul El } & morning peak & $3,896-4,020$ & 2,408 \\
Araby Str. & $\begin{array}{c}\text { afternoon peak } \\
\text { off peak }\end{array}$ & $2,248-2,264$ & 1,684 \\
& $1,970-1,986$ & 1,640 \\
\hline \multirow{2}{*}{ El Tarayan } & morning peak & $2000-2,206$ & $2,126-2,316$ \\
Str. & afternoon peak & $1,174-1,568$ & $1,277-1,676$ \\
& off peak & $1,232-1,504$ & $1,412-1,600$ \\
\hline
\end{tabular}

\subsection{Issues and shortcomings in the corridor}

Following extensive data collection and analysis, a number of significant shortcomings were identified in the corridor [6]. A primary shortcoming observed in the corridor was the large distance between official bus stops, exceeding one kilometer in some cases. This was considered to be the main reason for passengers to request bus drivers to stop at various locations that are unofficial stops. The persistence of this behavior and the willingness of bus drivers to accommodate such requests have compromised passengers' safety and often interrupt traffic on the street adjacent to the bus way, but also significantly decreasing level of bus service.

This is coupled with deficiencies in design of bus stop platforms. They are elementary and very small, not taking passenger demand into consideration, thus resulting in passengers standing on the street while waiting for the bus. Moreover, the platform has low quality equipment, lagging behind modern solutions in providing important information to passengers or making use of commercial opportunities (advertising). Such condition also decreases level of service to passengers and poses significant risk regarding safety of passengers. Common occurrence is bus overtaking on the two-lane bus way. This causes safety problems in busy intersections and fear among passengers. There is a general lack of discipline in bus drivers' behavior, which is facilitated by absence of driver supervision and control.

The presence of irregular terminals created by microbuses is a cause of traffic congestion. Inadequately regulated microbus terminals are mostly located at main intersections. The common behavior of microbus operators (a kind of informal sector) to compete for passengers negatively affects both the capacity of junctions and general safety, providing also a bad impression of the service and absence of regulation by the public transport authorities. In fact, serious institutional deficiency with split responsibilities (Cairo Governorate - Ministry of Transport - Ministry of Interior) exists in Cairo, as well as in whole Egypt, regarding urban transport planning, traffic management and regulation of public transport.
Traffic flow along the corridor is controlled manually by policemen at major intersections. Some intersections along the Mostafa El Nahas corridor already have traffic signals, poles and controllers installed, but still in the testing phase. Currently, physical changes in these intersections attempt to simplify traffic movements, such as closing left turns and instead setting up a U-turn $200 \mathrm{~m}$ after the intersection. However, these measures and the lack of a functioning signalized traffic control leads to long delays in intersection crossings during peak hours and to safety threats. The inadequate setting up of traffic lanes (including lanes for left or right turns) increases traffic problems in the corridor. Very few traffic lanes are designed to guide vehicles to turn left or right.

Crossing of Cairo's streets is a long and difficult endeavor on foot. There are very few designated and marked pedestrian crossings. This encourages pedestrians to cross streets anywhere and anytime. Due to the large width of the corridor, each pedestrian crossing point is hazardous, especially at the bus way lanes due to high speed buses.

Although there is designated and legal parking space, there are persistent parking problems such as cars parked perpendicular to the lanes and too close together, at the wrong angle, or parked in double rows, etc. It is important to notice that parking space is organized only in Mostafa El Nahas Str., being completely irregular along the other streets within the corridor. The parking supply inventory showed total of 1,638 regular parking spaces.

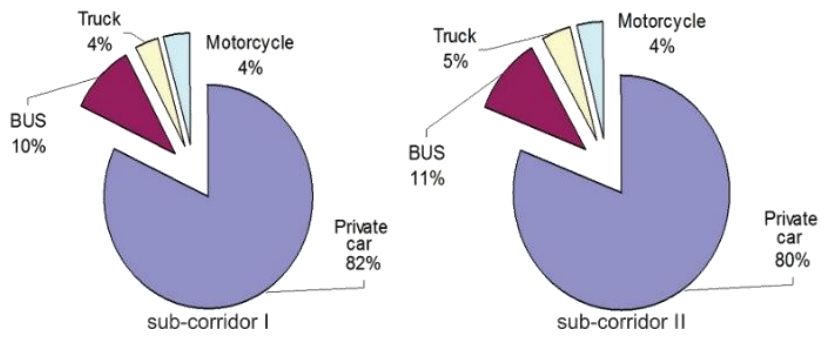

Figure 4. Composition of average traffic flow along subcorridors I and II [6]

Traffic flow along sub-corridor I is dominated by passenger cars, while buses, heavy vehicles and motorcycles reach $18 \%$. Similar traffic flow structure is recorded along sub-corridor II - passenger cars prevailing $(80 \%)$, other types of vehicles occupying $20 \%$. Composition of average traffic flows for both sub-corridors are presented in Figure 4. Stop time data (standstill time during the trip) were also collected along streets forming the corridor. Ratio of stop time and total measured travel time varies depending on the street, day in week and period of observation, and can be as high as $50 \%$. Dominant causes of stop are bus stops, for passenger boarding and disembarking, traffic lights and congestion. 


\section{PROPOSED MEASURES}

The shortcomings described above led to the proposal of the following solutions within the package of measures. These can be grouped in four areas: bus operations and infrastructure, traffic management, parking, and soft measures.

\subsection{Bus operations and infrastructure measures}

Operations Management Centre for buses, applying modern technical solutions, to manage overall operations of public transport is recommended as primary management measure. Bus terminals and bus dispatchers play a key role in providing efficient bus operations. For the operation of successful public transport, the following is crucial: updated operation plans/timetables, real time information on the status of the network, immediate reporting of disruptions, driving assistance for bus drivers and ex-post analysis of operations and adjustments.

Diverting certain lines may improve bus circulation inside the bus way. This measure will also reduce the high number of buses on crowded intersections. By converting certain portion of unofficial stops into official stops, the number and location of stops can be adjusted to passenger demand. Figure 5. shows the proposed map of bus stops in the Mostafa El Nahas corridor area. The blue and red colors signify opposite directions ( $A$ and $B$ ), while large circles represent busy intersections.

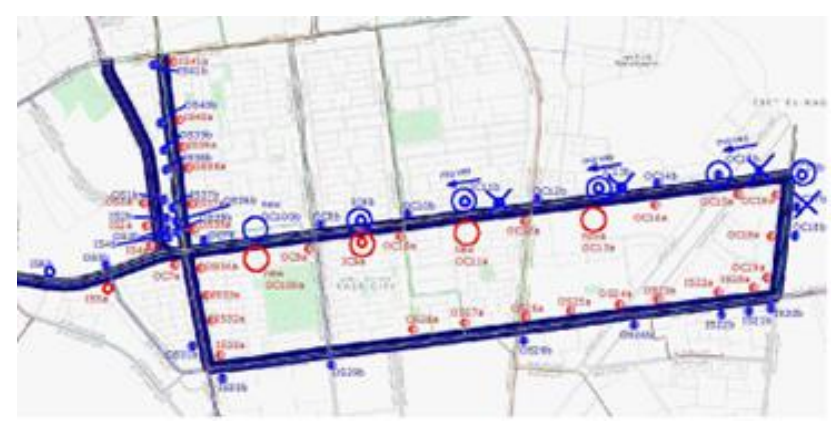

Figure 5. New arrangement of bus stops [6]

As a short-term solution to improve and control bus service regularity, the irregular microbus terminals should be relocated away from main intersections. In the long-term, it is important to introduce a modern management system for microbuses to be an integral component of public transport. Later, organized terminals and service stations shall be made for microbuses. The best way to do it is setting the operational standards and preparing bidding documents for private sector operators to compete on providing the service (i.e. franchising the lines). Such regulation has to be implemented in close cooperation and agreement with microbus operators to avoid possible problems and insurgency at the very sensitive private sector which, among others, includes significant social and ownership aspect.
The increased usage of public transport reduces huge traffic jams, time spent in traffic as well as number of vehicles on the streets. Furthermore, the use of public transport would result in reduction of pollutants emissions, and hence reduce the environmental pollution.

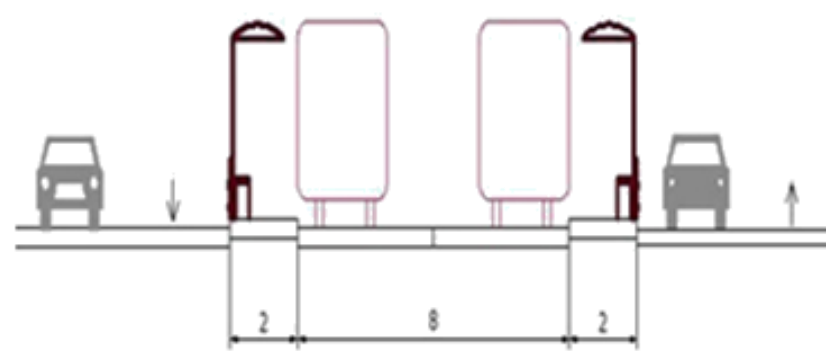

Figure 6. Redesigned cross section of bus stop [6]

Both new and existing stops on the bus lanes should be redesigned to the appropriate width and with modern facilities. Figure 6 . shows proposed design for new bus stop and shelters. They should be connected with the side of the street through pedestrian crossings, which are to be designed to reduce the speed of general traffic and thereby increase the safety of pedestrians. Figure 7 . shows a proposed new standard bus stop design where the yellow pedestrian zebra crossing is on a raised platform of the same height as the sidewalk, to facilitate easy movement of low mobility persons. This arrangement also causes vehicles on the main flow to slow down and reduce traffic safety risk.

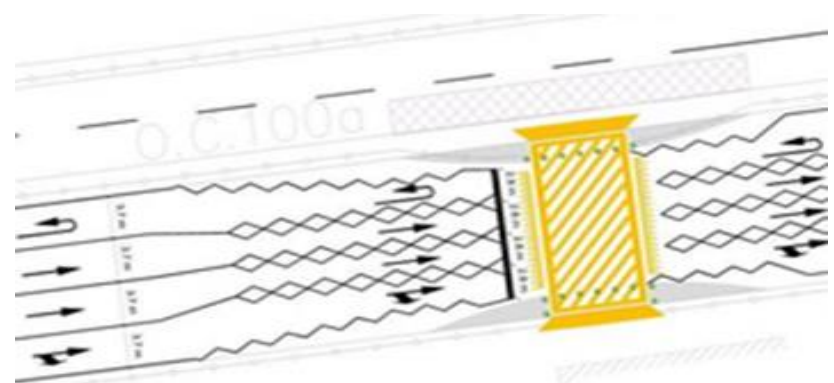

Figure 7. Platform widening for new stops [6]

In order to reduce or eliminate bus overtaking in the two-lane bus way, it is recommended that a supervisor service be established by the bus operator, along with a system to register and track improper driving behavior. Also, bus drivers should receive mandatory training. Later, this could be based on a video surveillance system.

If passengers can enter and leave buses more quickly it would reduce the time that buses are stopped at bus stops, especially during the peak periods. This could be facilitated by using low-entry buses with three doors. The construction of appropriate bus stops would reduce passengers waiting for or taking off bus on the street. 
At the moment, number of passengers do not fit at the bus stop because it is not properly constructed and can accommodate reduced number of passengers. Passengers are forced to stand on the street, where they are exposed to potential danger of road traffic injuries.

\subsection{Traffic management improvements}

Through equipping all intersections with traffic lights, it is expected that the prevailing low level of service at intersections will be improved. Proposed traffic lights locations are illustrated in Figure 8, which gives an overview of the Mostafa EI Nahas corridor where the green circles represent current traffic lights, and yellow circles represent proposed traffic light installation. New design of traffic lights is recommended, followed by modern ITS (Intelligent Transport Systems) solution in the $\mathrm{mid} /$ long-term period.

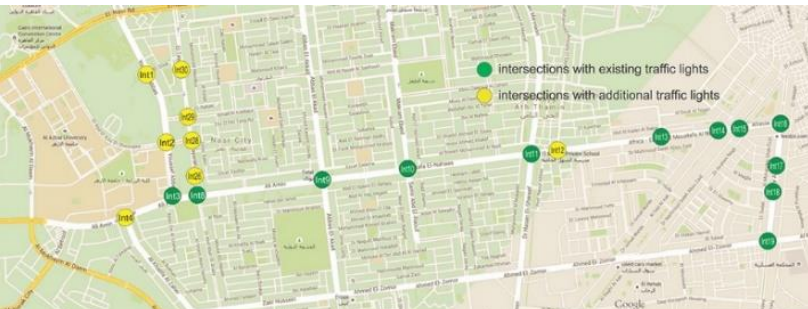

Figure 8. Traffic light intersection overview [6]

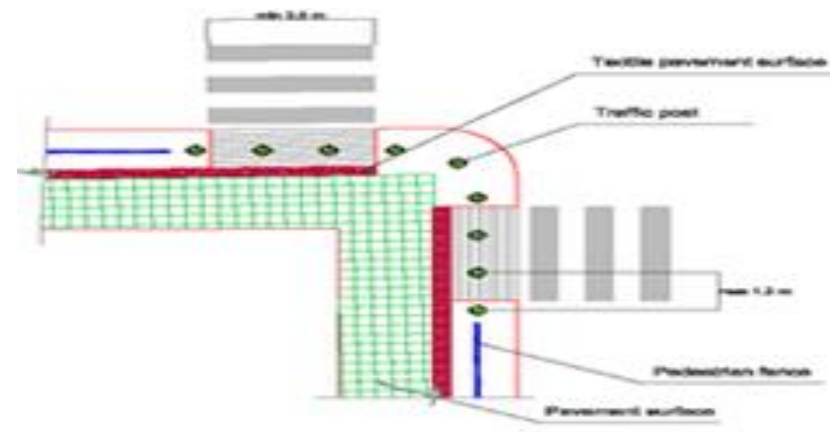

Figure 9. Proposed sidewalk [6]

By improving sidewalks and pedestrian crossings (Figure 9) it is proposed to create clearly marked and elevated zebra crossings to facilitate pedestrian movement along sidewalks and across traffic lanes. This is similar to the zebra crossing at the bus stops shown earlier (Figure 7).

Installation of fences along the bus way corridor is a measure preventing people from crossing the street at dangerous locations and directing them to designated crossings. Car parking on sidewalks is prevented by installing traffic posts, as presented in Figure 9.
Furthermore, unifying sidewalk standards will improve their quality and appearance, as well as benefit persons with low mobility. It is important to survey the interest in cycling then develop the infrastructure for traditional cycling facilities (cycle lanes, cycle paths, parking racks, traffic lights for bicycles, bicycle stop boxes, etc.).

Bike lanes, built by international standards would contribute to reduced $\mathrm{CO}_{2}$ emissions and decrease in road traffic injuries, which are common without a separate bicycle lane. Utilization of bicycle routes would reduce the time spent in traffic and cyclists would easily and safely get from one end of town to another. Increased usage of bicycles would improve the health of Cairo's population. This shall be reflected in increased recreation, and thus there would be an improvement in people's health and psycho-physical condition. However, although being proposed, this measure has to undergo serious survey and analysis, as noted above, knowing the common travelling behavior in Cairo.

\subsection{Parking measures}

Due to current inadequate parking spaces, buses, microbuses and cars park on sidewalks and unmarked places with reduced visibility, where pedestrians are at risk, which may lead to fatal consequences. Construction of standardized parking lots would reduce traffic congestion as well as road traffic injuries.

The two parking solutions are to be introduced in the busiest areas where the most irregular and double parking were observed. In order to force drivers to park their vehicles according to the proposed pattern (under an angle or similar), the proposed measures are better signposting and marking of the area designated for parking, landscaping to make a clear distinction between the road and parking segment, introducing pavement marking to identify parking lane width and parking spaces, and introducing parking bollards that prevent cars from parking at the wrong locations.

As shown in Figure 10, the new parking bay would have a total width of 6-7 $\mathrm{m}$ and will feature longitudinal parking with a small island between the main traffic lanes and the parking bay. Changing the pattern of parking from under an angle to parallel will reduce parking capacity in these sections. If this system shows its advantages (less traffic jams, higher speeds, better safety, more regularity in parking), the next step in the parking strategy will be introducing parking control and limited parking duration on these spots. The longer term parking would be moved to other areas with less demand. 


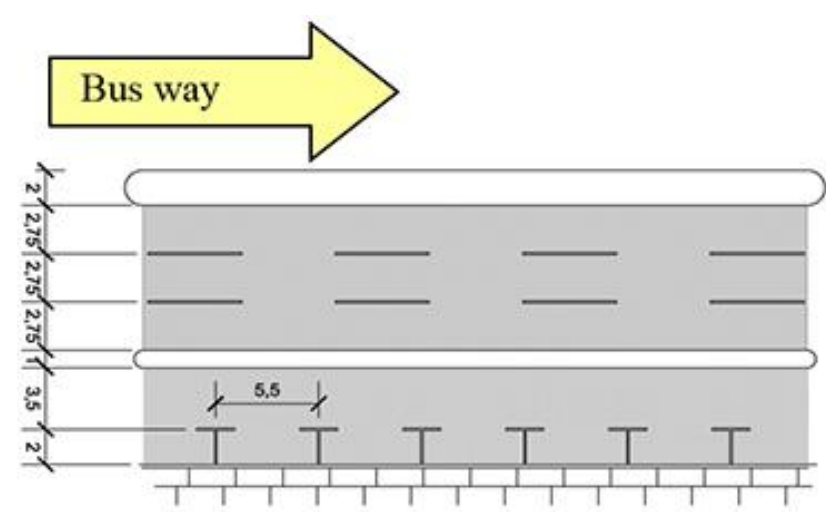

Figure 10. Proposed parking bays [6]

\subsection{Soft campaigns}

Soft campaigns would greatly help in improving the awareness and behavior of bus users, pedestrians and drivers. These could be divided into the following two groups: improvement of the bus way image and educational campaigns. Improvement of the bus way image could be done by making a recognized image (logo/pictogram) of the new system, unification of bus fleet design to the highest possible extent (long-term measure), unified design of bus shelters, improving information on bus stops (panels with maps, time table, promotion), information panels inside (modern) buses for promotion of the system (long-term measure).

Educational campaigns could consider dissemination of appropriate brochures and fliers among bus users, campaigning in shopping malls and centers by offering benefits for public transport users, campaigning among students (for cycling as well) and campaigning among business enterprises to encourage their employees to shift to public transport by giving them some benefits (paid public transport seasonal tickets, disseminating leaflets in favor of public transport, reducing free parking spaces, etc.).

\section{IMPORTANCE OF THE CORRIDOR RECONSTRUCTION IN THE INTERNATIONAL CONTEXT}

Corridor Mostafa El Nahas reconstruction has a great impact on Cairo's population as well as in the international context. The international significance lays in the fact that other cities and countries can implement a general strategy of Mostafa El Nahas corridor reconstruction in similar circumstances and thereby solve long-term problems that the population faces, in particular public transport users and inhabitants or workers within such corridors.

This strategy of reconstruction could be suitable for use in the cities with inefficient public transport services and increased utilization of passenger cars, which is significant for number of countries in the South and South-East Europe, Middle East, South Asia.
In particular, cities having wide main corridor streets would benefit from such strategic approach. Problems of non-functional or dysfunctional corridors are generally an international problem and have an international dimension. Therefore, countries need to work together, so the problems that the population faces could be solved.

Moreover, contribution of improved transport networks and new/reconstructed roads to the tourist industry comes in many forms including improvements in communications, redevelopment of land and stimulation of special projects. Social amenities will be enhanced by helping traffic flow and increasing accessibility of the area. The increased feasibility of commuting will bring new type of housing developments and have an immediate effect on land prices.

The effectiveness of the strategy application in other countries and on different continents depends on a wide experts' involvement of various profiles in solving problems that are significant, and mostly common, throughout the international community.

\section{CONCLUSION}

Corridor is a system made up of several components (infrastructure, transport and other services, and institutions for coordinating corridor activities (regulation)). It is important that policy makers appreciate the linkages between these components, particularly as the overall performance of a corridor is determined by the weakest component [7]. Major urban corridors must be adequate and well planned, they are "now and forever" and should be designed to add quality scenes to the metropolitan area.

Corridor Mostafa El Nahas reconstruction has a great impact on Cairo's population as well as in the international context. By the corridor reconstruction road safety is improved, time spent in traffic is reduced, traffic flow and overall view is improved. There is also a great potential to increase recreational aspect of life, by using bike lanes. Therefore, environmental pollution (in particular air and noise impacts) is reduced resulting in improvement of life quality. However, in order to validate the measures, the follow-up analysis should be performed to analyze the real effects achieved by applying the solution.

The strategy of corridor Mostafa El Nahas reconstruction in Cairo may serve as an example of how transport network reconstruction improves population's quality of life. Possibilities of this reconstruction application in the international context are numerous. Countries having problems with dysfunctional corridors should implement a strategy of reconstruction, in order to improve quality of life for its population, and therefore the environment. 
Furthermore, apart from proposed measures, Cairo Governorate should make the effort in improving its capacity by reducing shortage of transport planning and traffic engineering skills, as well as to improve financial resources allocation for urban transport to overcome chronic lack of investment.

Presented approach shows theoreticalmethodological model for reconstruction of main corridor streets with main goal to improve life quality and road safety. Professionally, the approach outlines steps and particular solutions that can be followed in future Cairo projects, and for similar cities with wide dysfunctional corridors, at the same time providing the possibility of training for further research and use in other countries at different continents. Finally, social component lies in general approach on how to improve quality of life and increase road safety.

\section{Acknowledgements}

The research presented in this paper was conducted with the support of the Cairo Governorate and MENA Rail Transport Consultants, and summarizes a part of the research made during Technical Assistance for Cairo - Integrated Corridor Management Study Mostafa El Nahas Corridor in Cairo, Egypt. The authors extend their thanks to all authorities for their kind assistance and understanding.

\section{References}

[1] Global Status Report on Road Safety 2015, World Health Organisation, Geneva, 2015.

[2] CO2 Emissions from Fuel Combustion 2015, International Energy Agency, Paris, 2015.

[3] Transforming Our World: The 2030 Agenda for Sustainable Development, United Nations, New York, 2015.

[4] Nešković, S.: Traffic and Ecology in the Concept of Sustainable Urban Development, 5th International Conference: Modern Trends in Traffic, Logistics and Ecology for Sustainable Development, Travnik, pp. 31-39, 2014.

[5] Maletin, M.: Planning and Design of Urban Traffic Infrastructure, Orion art, Belgrade, 2005.

[6] Cairo - Integrated Corridor Management Study Mostafa El Nahas Corridor, Final Report, MENA Rail Transport Consultants, Cairo, 2015.

[7] Nešković, S.: Traffic Corridors in the Function of Development of the Countries of Southeast Europe, 4th Conference with International Participation: Mobility and Road Safety, Travnik, pp. 20-27, 2013. 